\title{
Beetroot and radish production under different doses of green manures
}

\author{
Produção de beterraba e rabanete sobre diferentes doses de adubo verde \\ Producción de remolacha y rábano en diferentes dosis de abono verde
}

Received: 11/12/2021 | Reviewed: 11/20/2021 | Accept: 11/25/2021| Published: 12/06/2021

Vitor Abel da Silva Lino

ORCID: https://orcid.org/0000-0001-5330-7928

Universidade Federal Rural do Semi-Árido, Brazil

E-mail: vabel55@gmail.com

Francisco Bezerra Neto

ORCID: https://orcid.org/0000-0001-9622-206X

Universidade Federal Rural do Semi-Árido, Brazil

E-mail: bezerra@ufersa.edu.br

Jailma Suerda Silva de Lima

ORCID: https://orcid.org/0000-0001-7584-592X

Universidade Federal Rural do Semi-Árido, Brazil

E-mail: jailma@ufersa.edu.br

Elizangela Cabral dos Santos

ORCID: https://orcid.org/0000-0002-7074-3147

Universidade Federal Rural do Semi-Árido, Brazil

E-mail: elizangelacabral@ufersa.edu.br

Renato Leandro da Costa Nunes

ORCID: https://orcid.org/0000-0001-5792-2442

Instituto Federal do Ceará, Brazil

E-mail: renatoleandro.ce@ hotmail.com

Natan Medeiros Guerra

ORCID: https://orcid.org/0000-0002-4222-7102

Universidade Federal Rural do Semi-Árido, Brazil

E-mail: ntnguerra@gmail.com

Francisca Karla Kelly da Silva Lino

ORCID: https://orcid.org/0000-0003-3319-0317

Universidade Federal Rural do Semi-Árido, Brazil

E-mail: karlakellysilva12@gmail.com

Jolinda Mércia de Sá

ORCID: https://orcid.org/0000-0003-4953-2641

Universidade Federal de Campina Grande, Brazil

E-mail: jolindamercia@gmail.com

Rose Paula Desravines

ORCID: https://orcid.org/0000-0003-4981-9570

Universidade Federal Rural do Semi-Árido, Brazil

E-mail: rose.desravines@ alunos.ufersa.edu.br

Aridênia Peixoto Chaves

ORCID: https://orcid.org/0000-0002-2184-2536

Universidade Federal Rural do Semi-Árido, Brazil

E-mail: aridenia.peixoto@hotmail.com

Vania Christina do Nascimento Porto

ORCID: https://orcid.org/0000-0002-0352-0162

Universidade Federal Rural do Semi-Árido, Brazil

E-mail: vania@ufersa.edu.br

\begin{abstract}
Green manuring with spontaneous species from Caatinga biome has become an important strategy in production vegetables. One of the great challenges in tuberous vegetables production is to define an optimized quantity that provides a high productive yield with economic efficiency of production system. The objective of this study was to optimize agronomically and economically the production and its components of tuberous crops of beetroot and radish when manured with different amounts of green manures biomass, Merremia aegyptia and Calotropis procera from Caatinga biome, in two cropping seasons. The experimental design was a randomized complete block with five treatments and five replications. Treatments consisted of green manures amounts $\left(16,26,36,46,56 \mathrm{tha}^{-1}\right)$. The maximum agronomic efficiency of beetroot and radish was obtained with incorporation of 49.87 and $39.43 \mathrm{tha}^{-1} \mathrm{of} M$. aegyptia and $C$. procera, respectively, and the production maximum economic efficiency was reached when 36.14 and $36.48 \mathrm{t} \mathrm{ha}^{-1}$, respectively, of biomass of these green manures were added to the soil. The returns rate obtained in
\end{abstract}


beetroot and radish cultivation using the manures optimized amounts were 1.42 and 1.32 reais obtained for each real invested in the production of these tuberous.

Keywords: Beta vulgaris; Calotropis procera; Merremia aegyptia; Optimized green manures doses; Raphanus sativus.

\section{Resumo}

A adubação verde com espécies espontâneas do bioma Caatinga tem-se tornado uma importante estratégia na produção de hortaliças. Um dos grandes desafios na produção de tuberosas é definir uma quantidade otimizada que proporcione um alto rendimento produtivo com eficiência econômica do sistema produção. O objetivo deste estudo foi otimizar agronômica e economicamente a produção e seus componentes das culturas tuberosas de beterraba e rabanete adubadas com diferentes quantidades de biomassa dos adubos verdes, Merremia aegyptia e Calotropis procera do bioma Caatinga, em duas safras. O delineamento experimental foi em blocos completos casualizados com cinco tratamentos e cinco repetições. Os tratamentos consistiram em quantidades equitativas dos adubos verdes (16, 26, 36, 46, 56 t ha-1). A máxima eficiência agronômica da beterraba e rabanete foi obtida com a incorporação de 49,87 e 39,43 t ha-1 de $M$. aegyptia e $C$. procera, respectivamente, e a máxima eficiência econômica da produção foi alcançada quando 36,14 e 36,48 t ha-1, respectivamente, de biomassa desses adubos verdes foram adicionados ao solo. As taxas de retorno obtidas no cultivo da beterraba e rabanete com as quantidades otimizadas de adubos foram de 1,42 e 1,32 reais obtidos para cada real investido na produção dessas tuberosas.

Palavras-chave: Beta vulgaris; Calotropis procera; Merremia aegyptia; Doses de adubos verdes otimizadas; Raphanus sativus.

\section{Resumen}

El abono verde con especies espontáneas del bioma de Caatinga se ha convertido en una estrategia importante en la producción de hortalizas. Uno de los grandes desafíos en la producción de tuberosas es definir una cantidad optimizada que brinde un alto rendimiento productivo con eficiencia económica del sistema de producción. El objetivo de este estudio fue optimizar agronómica y económicamente la producción y sus componentes de cultivos tuberosas de remolacha y rábano cuando se abonan con diferentes cantidades de biomasa de los abonos verdes, Merremia aegyptia y Calotropis procera del bioma Caatinga, en dos temporadas de cultivo. El diseño experimental fue un bloque completo al azar con cinco tratamientos y cinco repeticiones. Los tratamientos consistieron en cantidades de los abonos verdes $\left(16,26,36,46,56 \mathrm{t} \mathrm{ha}^{-1}\right)$. La máxima eficiencia agronómica de remolacha y rábano se obtuvo con la incorporación de 49,87 y 39,43 t ha-1 de $M$. aegyptia y $C$. procera, respectivamente, y la máxima eficiencia económica de producción se alcanzó cuando 36,14 y 36,48 t ha ${ }^{-1}$, respectivamente, de biomasa de estos abonos verdes se agregaron al suelo. La rentabilidad obtenida en el cultivo de remolacha y rábano utilizando las cantidades optimizadas de abonos fue de 1,42 y 1,32 reales obtenidos por cada real invertido en la producción de estas tuberosas.

Palabras clave: Beta vulgaris; Calotropis procera; Merremia aegyptia; Dosis optimizadas de fertilizantes verdes; Raphanus sativus.

\section{Introduction}

In Brazil, the area planted with beet is 18,000 hectares (Santos et al., 2020), and with radish is not very expressive, planted mainly in the green belts of the large cities, with production in 2017 of 14,937 and $118 \mathrm{t}$, respectively for beet and radish (IBGE, 2021). The production costs in 2017 were 13,850.00 $\mathrm{R} \$ \mathrm{ha}^{-1}$ for beet and 17,472.94 $\mathrm{R} \$ \mathrm{ha}^{-1}$ for radish (EMATER-DF, 2021), and their mean productivities are 40.94 and $16.60 \mathrm{t} \mathrm{ha}^{-1}$ for beetroot and radish (Martins et al., 2017; Aguiar et al., 2021). The correct use of fertilization corrects the soil deficiency and provides nutrients for plants (Batista et al., 2016).

Chemical fertilization and with animal manure are techniques commonly used in the vegetables production (Souza, 2018). But, as these inputs are expensive, producers have opted for the use of green manures. However, there is a lack of technical information on the use of these manures in vegetable production systems, especially in the Brazilian semi-arid region. An alternative in the cultivation of tuberous crops in a semi-arid environment has been the use of spontaneously growing species that are easily available in the region's biome (Nunes et al., 2020).

Some species of the Caatinga biome are alternatives for fertilizing vegetables, due to their qualities as "good fertilizers". They provide nutrients, and have excellent biomass with low $\mathrm{C} / \mathrm{N}$ ratio, which provides faster decomposition and 
release of nutrients for the plants (Silva et al., 2019). Hairy woodrose can produce $36 \mathrm{t} \mathrm{ha}^{-1}$ of green biomass containing on dry basis $2.62 \% \mathrm{~N}, 0.17 \% \mathrm{P}, 1.20 \% \mathrm{~K}, 0.90 \mathrm{Ca}$ and $1.08 \mathrm{Mg}$. The roostertree can produce $51 \mathrm{t} \mathrm{ha}^{-1}$ of green biomass containing on dry basis $1.53 \% \mathrm{~N}, 4.0 \% \mathrm{P}, 1.57 \% \mathrm{~K}, 0.93 \% \mathrm{Ca}$ and $0.73 \%$ of $\mathrm{Mg}$ (Bezerra Neto et al., 2019).

Among these species are Merremia aegyptia and the Calotropis procera. There are few works with these species, but they show positive results in terms of increased productivity. Bezerra Neto et al. (2019), using C. procera in the fertilization of carrot and cowpea intercropping, obtained a productivity of $17.31 \mathrm{t} \mathrm{ha}^{-1}$ and $1.29 \mathrm{t} \mathrm{ha}^{-1}$ for carrot and cowpea beans, respectively, by using 48.05 and $45.51 \mathrm{t} \mathrm{ha}^{-1}$ of C. procera, respectively. In turn, Silva et al. (2020), also working with carrot and cowpea intercropping fertilized with $M$. aegyptia, obtained a productivity of commercial roots of $29.47 \mathrm{t} \mathrm{ha}^{-1}$ and productivity of green grains of $3.13 \mathrm{tha}^{-1}$ using 32.69 and $50.17 \mathrm{t} \mathrm{ha}^{-1}$ of M. aegyptia, respectively.

The main problem surrounding the use of these species as green manure is to obtain quantities that optimize the production and its components of the tuberous crops, in order to achieve the maximum agronomic and economic efficiency in their cultivation. The objective of this work was to optimize agronomically and economically the production and its components of the radish and beetroot cultures, manured with different green manures biomass amounts, Merremia aegyptia and Calotropis procera from Caatinga biome, in two cropping seasons.

\section{Methodology}

\subsection{Locations and environmental conditions}

Experiments were conducted from August to September 2016 and 2018, at the Experimental Farm 'Rafael Fernandes' of Universidade Federal Rural do Semi-Árido (UFERSA), located in the district of Lagoinha, $20 \mathrm{~km}$ from the municipality of Mossoró, RN, in geographic coordinates $5^{\circ} 03$ ' 37 " S, 37 $27^{\circ}$ ' 50" W, altitude of $80 \mathrm{~m}$.

The region's climate according to the Köppen classification is (BSh), dry and very hot, with two seasons: a dry season, which usually occurs from June to January, and a rainy season from February to May (Beck et al., 2018). Climatic data during the experimental period are shown in Table 1 (INMET, 2019).

Table 1. Climatic data in the period of experiments development.

\begin{tabular}{ccccccc}
\hline \multirow{2}{*}{$\begin{array}{c}\text { Cropping } \\
\text { seasons }\end{array}$} & Minimum & Mean & Maximum & $\begin{array}{c}\text { Relative } \\
\text { humidity } \\
(\%)\end{array}$ & $\begin{array}{c}\text { Solar radiation } \\
\left(\mathrm{MJ} \mathrm{m}^{-2}\right)\end{array}$ & $\begin{array}{c}\text { Wind speed } \\
\left(\mathrm{m} \mathrm{s}^{-1}\right)\end{array}$ \\
\hline 2016 & 22.4 & 27.8 & 33.3 & 60.8 & 23.6 & $1.0-4.5$ \\
2018 & 20.1 & 28.5 & 37.0 & 73.8 & 20.8 & $1.6-4.5$ \\
\hline
\end{tabular}

Source: Authors.

The soils in the experimental areas are classified as vermeho-amarelo distrófico with sandy-loam texture (Santos et al., 2018). In each experimental area, soil samples of 0-20 cm surface layer were collected, and analysed some chemical chacteristics. The results of these analyses are shown in Table 2.

Table 2. Soil chemical analysis prior to incorporation of the green manures in the first and second cropping season.

\begin{tabular}{|c|c|c|c|c|c|c|c|c|c|c|c|c|c|}
\hline \multicolumn{14}{|c|}{ Chemical chacteristics } \\
\hline \multirow{2}{*}{$\begin{array}{c}\text { Cropping } \\
\text { seasons }\end{array}$} & \multirow{2}{*}{$\begin{array}{c}\mathrm{N} \\
\mathrm{g} \mathrm{kg}^{-1} \\
\end{array}$} & \multirow{2}{*}{$\begin{array}{c}\mathrm{pH} \\
\left(\mathrm{H}_{2} \mathrm{O}\right)\end{array}$} & \multirow{2}{*}{$\begin{array}{c}\mathrm{EC} \\
\mathrm{dS} \mathrm{m}^{-1}\end{array}$} & \multirow{2}{*}{$\begin{array}{l}\text { O.M. } \\
\mathrm{g} \mathrm{kg}^{-1}\end{array}$} & $\mathrm{P}$ & $\mathrm{K}^{+}$ & $\mathrm{Na}^{+}$ & $\mathrm{Ca}^{2+}$ & $\mathrm{Mg}^{2+}$ & $\mathrm{Cu}$ & $\mathrm{Fe}$ & $\mathrm{Mn}$ & $\mathrm{Zn}$ \\
\hline & & & & & \multicolumn{3}{|c|}{$\mathrm{mg} \mathrm{dm}^{-3}$} & \multicolumn{2}{|c|}{$\mathrm{cmol}_{\mathrm{c}} \mathrm{dm}^{-3}$} & \multicolumn{4}{|c|}{$\mathrm{mg} \mathrm{dm}^{-3}$} \\
\hline 2016 & 0.42 & 6.60 & 0.10 & 3.65 & 34.20 & 69.20 & 19.0 & 3.10 & 0.80 & 0.29 & 2.86 & 11.40 & 7.35 \\
\hline 2018 & 0.35 & 6.10 & 0.24 & 4.97 & 22.80 & 64.70 & 13.7 & 3.28 & 0.78 & 0.10 & 1.91 & 11.67 & 2.63 \\
\hline
\end{tabular}




\subsection{Experimental design and treatments}

The experimental design used in both experiments of each crop was in complete randomized blocks, with five treatments and five repetitions. The treatments consisted of mixtures of equal amounts of Merremia aegyptia (Convolvulaceae) and Calotropis procera (Apocynaceae) biomass in the following amounts (16, 26, 36, 46 and $56 \mathrm{t} \mathrm{ha}^{-1}$ on a dry basis). These quantities were defined based on the quantities tested in researches with carrot and beetroot carried out in a semiarid environment by Favacho et al. (2017) and Morais et al. (2018). A treatment without fertilization (control) was used in each experiment.

The total area of the experimental plots was $1.44 \mathrm{~m}^{2}$ with a useful area of $0.80 \mathrm{~m}^{2}$, containing 80 plants of beetroot or of radish in the spacing of $0.20 \mathrm{~m} \mathrm{x} 0.05 \mathrm{~m}$. Each experimental plot was formed of six rows, containing 24 plants per linear meter of beetroot or radish. The beetroot cultivar used in the experiment was 'Early Wonder', and the radish cultivar was 'Crimson Gigante'.

\subsection{Experiments conducting and green manure}

The soil preparation consisted of plowing and harrowing, followed by raising the beds with the aid of a backhoe. Afterwards, in pre-planting a solarization was carried out for 30 days with $30 \mu \mathrm{m}$ transparent plastic (Vulca Brilho Bril Fles ${ }^{\circledR}$ ) according to Pereira et al. (2016).

The green manures (M. aegyptia and C. procera) were collected from native vegetation in several locations in the rural area of Mossoró, RN, before the beginning of their blooms. The plants were crushed in a conventional forage machine into pieces of two or three centimeters, which were dehydrated at room temperature until reaching a moisture content of $10 \%$ and then subjected to laboratory analysis, obtaining the following chemical compositions, shown in Table 3 .

Table 3. Macronutrient contents in Merremia aegyptia and Calotropis procera biomass and $\mathrm{C} / \mathrm{N}$ ratio in the first and second cropping season.

\begin{tabular}{cccccccc}
\hline \multirow{2}{*}{ Green manures } & $\begin{array}{c}\text { Cropping } \\
\text { seasons }\end{array}$ & $\mathrm{N}$ & $\mathrm{P}$ & $\mathrm{K}$ & $\mathrm{Ca}$ & $\mathrm{Mg}$ & \multirow{2}{*}{$\mathrm{C} / \mathrm{N}$} \\
\cline { 3 - 7 } & 2016 & 14.80 & 2.52 & 11.95 & 8.11 & 8.15 & $21: 1$ \\
\multirow{2}{*}{ M. aegyptia } & 2018 & 16.60 & 2.79 & 20.80 & 19.35 & 7.07 & $20: 1$ \\
\hline \multirow{2}{*}{ C. procera } & 2016 & 18.40 & 3.14 & 14.50 & 16.30 & 13.35 & $25: 1$ \\
& 2018 & 21.90 & 1.92 & 20.90 & 17.00 & 9.22 & $27: 1$ \\
\hline
\end{tabular}

Source: Authors.

The green manure used in the experiment consisted of equal amounts of M. aegyptia and C. procera biomass, in the proportion of 1:1. The incorporation of the green manures dry mass (DM) was carried out 20 days before sowing, as recommended by Bezerra Neto et al. (2019), and the material was incorporated into the $0-0.20 \mathrm{~m}$ layer of soil in the experimental plots manually with the aid of hoes. Irrigations were carried out daily using a micro sprinkler irrigation system, provided in two shifts, morning and afternoon, during the experiment period, with an $8 \mathrm{~mm}$ blade applied each day, in order to maintain the soil in its field capacity.

The plantings in the first and second season were carried out by direct sowing radish (06/20/2016) and beetroot (06/13/2016), leaving only one plant per hole. Manual weeding was carried out whenever necessary. The radish and beetroot were harvested at 29 and 70 DAS, respectively. In the second season, the same procedures were followed for the cultivation of the radish $(08 / 15 / 2018)$ and beetroot $(08 / 01 / 2018)$. 


\subsection{Evaluated parameter and economic efficiency indicators}

In the radish culture, the following characteristics were evaluated: plant height (measured with a ruler, from the ground level to the highest leaf, values expressed in $\mathrm{cm}$ ), number of leaves per plant (obtained by counting), DM of shoots and roots (obtained by weighing the leaves and roots, respectively, values expressed in $\mathrm{t} \mathrm{ha}^{-1}$ ), total and commercial productivity, and scrap root productivity.

For the cultivation of beetroot, the following determinations were made: plant height, number of leaves per plant, DM of shoots and roots, total and commercial productivity, and classification according to root diameter (DR): extra (DR> 4 and $<5 \mathrm{~cm}$ ), extra $\mathrm{A}(\mathrm{DR} \geq 5$ and $<6 \mathrm{~cm}$ ), extra $\mathrm{AA}(\mathrm{DR} \geq 6$ and $<7 \mathrm{~cm})$ and great $(\mathrm{DR}>7 \mathrm{~cm})$; cracked, bruised, forked roots or roots smaller than $4 \mathrm{~cm}$ are classified as scrap (Silva et al., 2019).

The indicators of economic efficiency, gross and net income, rate of return and profitability index were determined in both cultures. Gross income (RB) was obtained by multiplying the production per hectare by the value of the product ( $\mathrm{R} \$ 1.53$ $\mathrm{kg}^{-1}$ for beetroot and $\mathrm{R} \$ 4.08 \mathrm{~kg}^{-1}$ for radish) paid to the producer at market level in the region in October 2016 and 2018, expressed in $\mathrm{R} \$ \mathrm{ha}^{-1}$. Net income (RL) was calculated by the following expression: RL $=\mathrm{RB}-\mathrm{TC}$, where TC is the total cost of production, resulting from the sum of all expenses with inputs and labor in each treatment, also expressed in $\mathrm{R} \$ \mathrm{ha}^{-1}$. The rate of return (TR) was obtained by the expression: $T R=\mathrm{RB} / \mathrm{TC}$. The profit margin was obtained from the ratio between RL and $\mathrm{RB}$, expressed as percentage.

\subsection{Statistical analysis}

A joint analysis of variance covering the two cropping seasons was performed for beetroot and radish variables, using the Sisvar software (Ferreira, 2019). When a significant interaction between the amounts of the M. aegyptia and C. procera mixture and the cropping seasons was recorded, it was partitioned and a polynomial or exponential model response function was adjusted to each variable, using Systat Software, 2021, where the point of maximum physical (agronomic) or economic efficiency was estimated.

The response function was obtained based on the follo wing criteria: biological logic of the variable, significance of the mean square of the regression residue (MSRR), high determination coefficient $\left(\mathrm{R}^{2}\right)$ and significance of the parameters of the regression function. The $\mathrm{F}$ test at $5 \%$ probability was used to compare the average values between the cropping seasons, and between the average value of the maximum physical or economic efficiency and the average value of the control treatment that did not receive green manure.

\section{Results and Discussion}

The results of the analyses of variance for the beetroot agronomic characteristics and economic indicators are presented in Table 1. Significant interactions were detected between amounts of the Merremia aegyptia and Calotropis procera biomass and cropping seasons for the most of agronomic characteristics and all economic indicators evaluated in beetroot, except for the total and commercial productivity of roots, and the productivity of scrap roots (Table 4). 
Table 4. Mean values for the control $\left(\mathrm{T}_{\mathrm{c}}\right)$, the treatment of maximum physical or economic efficiency (MPE or MEE) and of the treatments manured $\left(\mathrm{T}_{\mathrm{m}}\right)$ in the agro-economic characteristics of the beetroot culture manured with M. aegyptia and C. procera biomass in two cropping systems.

\begin{tabular}{|c|c|c|c|c|c|c|}
\hline \multirow{3}{*}{ Comparison treatments } & \multicolumn{3}{|c|}{$\begin{array}{l}\text { Dry mass of shoots } \\
\left(\mathrm{t} \mathrm{ha}^{-1}\right)\end{array}$} & \multicolumn{3}{|c|}{$\begin{array}{c}\text { Dry mass of roots } \\
\left(\mathrm{t} \mathrm{ha}^{-1}\right)\end{array}$} \\
\hline & \multicolumn{3}{|c|}{ Cropping seasons } & \multicolumn{3}{|c|}{ Cropping seasons } \\
\hline & 2016 & 2018 & 2016-2018 & 2016 & 2018 & 2016-2018 \\
\hline Control (without manuring, $\mathrm{T}_{\mathrm{c}}$ ) & $0.11 \mathrm{bB}$ & $0.23 \mathrm{bA}$ & $0.17 \mathrm{~b}$ & $0.12 \mathrm{bB}$ & $0.28 \mathrm{bA}$ & $0.20 \mathrm{~b}$ \\
\hline MPE treatment & $0.30 \mathrm{aB}$ & $0.65 \mathrm{aA}$ & $0.48 \mathrm{a}$ & $0.14 \mathrm{aB}$ & $0.88 \mathrm{aA}$ & $0.51 \mathrm{a}$ \\
\hline Manured treatments $\left(\mathrm{T}_{\mathrm{m}}\right)$ & & & $0.38^{+}$ & & & $0.44^{+}$ \\
\hline \multirow{2}{*}{$\mathrm{CV}(\%)$} & \multirow{2}{*}{\multicolumn{3}{|c|}{$\begin{array}{c}28.97 \\
\begin{array}{c}\text { Productivity of total roots } \\
(\mathbf{t ~ h a}\end{array}\end{array}$}} & & & 28.00 \\
\hline & & & & \multicolumn{3}{|c|}{$\begin{array}{c}\text { Productivity of commercial roots } \\
\qquad\left(\mathrm{t} \mathrm{ha}^{-1}\right)\end{array}$} \\
\hline Control (without manuring, $\mathrm{T}_{\mathrm{c}}$ ) & & & $7.18 \mathrm{~b}$ & & & $6.53 \mathrm{~b}$ \\
\hline MPE treatment & & & $18.40 \mathrm{a}$ & & & $17.58 \mathrm{a}$ \\
\hline Manured treatments $\left(\mathrm{T}_{\mathrm{m}}\right)$ & & & $15.79^{+}$ & & & $14.97^{+}$ \\
\hline Cropping season 2016 & & & $16.18 \mathrm{a}$ & & & $15.42 \mathrm{a}$ \\
\hline Cropping season 2018 & & & $12.53 \mathrm{~b}$ & & & $11.70 \mathrm{~b}$ \\
\hline \multirow[t]{2}{*}{$\mathrm{CV}(\%)$} & \multirow{2}{*}{\multicolumn{3}{|c|}{$\begin{array}{c}17.58 \\
\begin{array}{c}\text { Productivity of scrap roots } \\
\left(\mathbf{t} \text { ha }^{-1}\right)\end{array}\end{array}$}} & \multirow{2}{*}{\multicolumn{3}{|c|}{$\begin{array}{c}\text { Productivity of great roots } \\
\left(\mathrm{t} \mathrm{ha}^{-1}\right)\end{array}$}} \\
\hline & & & & & & \\
\hline Control (without manuring, $\mathrm{T}_{\mathrm{c}}$ ) & $0.30 \mathrm{bB}$ & $1.56 \mathrm{aA}$ & $0.93 \mathrm{a}$ & & & $7.03 \mathrm{~b}$ \\
\hline MPE treatment & $1.38 \mathrm{aA}$ & $0.96 \mathrm{bB}$ & $1.17 \mathrm{~b}$ & & & $10.36 \mathrm{a}$ \\
\hline Manured treatments $\left(\mathrm{T}_{\mathrm{m}}\right)$ & & & $0.82^{+}$ & & & $8.14^{+}$ \\
\hline Cropping season 2016 & & & & & & $10.13 \mathrm{a}$ \\
\hline Cropping season 2018 & & & & & & $3.93 \mathrm{~b}$ \\
\hline \multirow[t]{2}{*}{$\mathrm{CV}(\%)$} & & & 45.70 & & & 36.89 \\
\hline & \multicolumn{3}{|c|}{$\begin{array}{c}\text { Productivity of extra roots } \\
\left(\mathrm{t} \mathrm{ha}^{-1}\right)\end{array}$} & \multicolumn{3}{|c|}{$\begin{array}{c}\text { Productivity extra A roots } \\
\left(\mathrm{t} \mathrm{ha}^{-1}\right)\end{array}$} \\
\hline Control (without manuring, $\mathrm{T}_{\mathrm{c}}$ ) & $2.02 \mathrm{aA}$ & $2.08 \mathrm{bA}$ & $2.05 \mathrm{a}$ & $2.25 \mathrm{aA}$ & $0.64 \mathrm{bB}$ & $1.45 \mathrm{~b}$ \\
\hline MPE treatment & $0.78 \mathrm{bB}$ & $2.87 \mathrm{aA}$ & $1.82 \mathrm{~b}$ & $2.21 \mathrm{aB}$ & $2.95 \mathrm{aA}$ & $2.09 \mathrm{a}$ \\
\hline Manured treatments $\left(\mathrm{T}_{\mathrm{m}}\right)$ & & & $1.19^{+}$ & & & $2.06^{+}$ \\
\hline \multirow[t]{2}{*}{$\mathrm{CV}(\%)$} & & & 39.78 & & & 36.90 \\
\hline & Produ & $\begin{array}{l}\text { vity extra AA } \\
\left(\text { t ha }^{-1}\right)\end{array}$ & oots & & & \\
\hline Control (without manuring, $\mathrm{T}_{\mathrm{c}}$ ) & $2.15 \mathrm{bA}$ & $0.69 \mathrm{bB}$ & $1.42 \mathrm{~b}$ & & & \\
\hline MPE treatment & $3.02 \mathrm{aB}$ & $4.86 \mathrm{aA}$ & $3.94 \mathrm{a}$ & & & \\
\hline Manured treatments $\left(\mathrm{T}_{\mathrm{m}}\right)$ & & & $3.22^{+}$ & & & \\
\hline \multirow[t]{2}{*}{$\mathrm{CV}(\%)$} & & & 40.56 & & & \\
\hline & & $\begin{array}{l}\text { ross income } \\
\left(\mathbf{R} \$ \text { ha }^{-1}\right)\end{array}$ & & & $\begin{array}{l}\text { Jet income } \\
\left(\mathbf{R} \$ \mathbf{h a}^{-1}\right)\end{array}$ & \\
\hline Control (without manuring, $\mathrm{T}_{\mathrm{c}}$ ) & $14,797.52$ bA & $10,233.41 \mathrm{bB}$ & $12,515.46 \mathrm{~b}$ & $459.27 \mathrm{bA}$ & $-104.84 \mathrm{bB}$ & $177.21 \mathrm{~b}$ \\
\hline MPE treatment & $28,545.39 \mathrm{aA}$ & $26,870.83 \mathrm{aB}$ & $26,942.76 \mathrm{a}$ & $11,202.17 \mathrm{aA}$ & $6,964.61 \mathrm{aB}$ & $7,380.83 \mathrm{a}$ \\
\hline Manured treatments $\left(\mathrm{T}_{\mathrm{m}}\right)$ & & & $24,207.80^{+}$ & & & $5,772.83^{+}$ \\
\hline \multirow[t]{2}{*}{$\mathrm{CV}(\%)$} & & & 10.35 & & & 48.02 \\
\hline & \multicolumn{3}{|c|}{ Rate of return } & \multicolumn{3}{|c|}{ Profit margin $(\%)$} \\
\hline Control (without manuring, $\mathrm{T}_{\mathrm{c}}$ ) & $1.03 \mathrm{aB}$ & $0.99 \mathrm{bB}$ & $1.01 \mathrm{~b}$ & $2.97 \mathrm{bA}$ & $-1.13 \mathrm{bB}$ & $0.93 \mathrm{~b}$ \\
\hline MPE treatment & $1.71 \mathrm{aA}$ & $1.31 \mathrm{bA}$ & $1.44 \mathrm{a}$ & $40.86 \mathrm{aA}$ & $22.68 \mathrm{aB}$ & $28.63 \mathrm{a}$ \\
\hline Manured treatments $\left(\mathrm{T}_{\mathrm{m}}\right)$ & & & $1.31^{+}$ & & & $23.24^{+}$ \\
\hline $\mathrm{CV}(\%)$ & & & 10.08 & & & 35.23 \\
\hline
\end{tabular}

* Means followed by the same small letter in the column and capital letter in the row do not differ by $\mathrm{F}$ test at the $5 \%$ probability.

+ Mean of manured treatments is significantly different from the control treatment mean by the $\mathrm{F}$ test at the $5 \%$ probability level.

Source: Authors.

\subsection{Agronomic characteristics of beetroot culture}

The total and commercial beet roots productivities increased with the increase in the amounts of M. aegyptia and C. procera biomass incorporated into the soil, in a polynomial model, reaching the maximum values of 18.40 and $17.58 \mathrm{t}$ ha ${ }^{-1}$ for amounts of 48.55 and $49.87 \mathrm{t} \mathrm{ha}^{-1}$ of green manures biomass (Figure 1A). Partitioning the interactions that occurred in the productivity of scrap roots and in the dry mass of beet roots, it was observed that there was a decrease in these characteristics with the increase in the green manures biomass amount incorporated in the soil, in exponential or polynomial model. The 
maximum values of scrap roots productivity of 1.38 and $0.96 \mathrm{t} \mathrm{ha}^{-1}$ was obtained in the first and second cropping season, respectively, in the green manures amount of $16.00 \mathrm{t} \mathrm{ha}^{-1}$, according to equations shown in the Figure 1B. On the other hand, the optimized productivity of scrap roots of $1.14 \mathrm{t} \mathrm{ha}^{-1}$ was observed in the green manures amount of $16.00 \mathrm{t} \mathrm{ha}^{-1}$ (Figure $1 \mathrm{~B}$ ).

Figure 1. Productivity of total roots - PTR and productivity of commercial roots - PCR (A), productivity of scrap roots - PSR (B), dry mass of shoots - DMS (C), and dry mass of roots - DMR (D) of beetroot as a function of amounts of M. aegyptia and C. procera biomass in two cropping seasons (CS1 and CS2). ** $=\mathrm{P}<0.01$; $^{*}=\mathrm{P}<0.05$; OT $=$ Optimized.
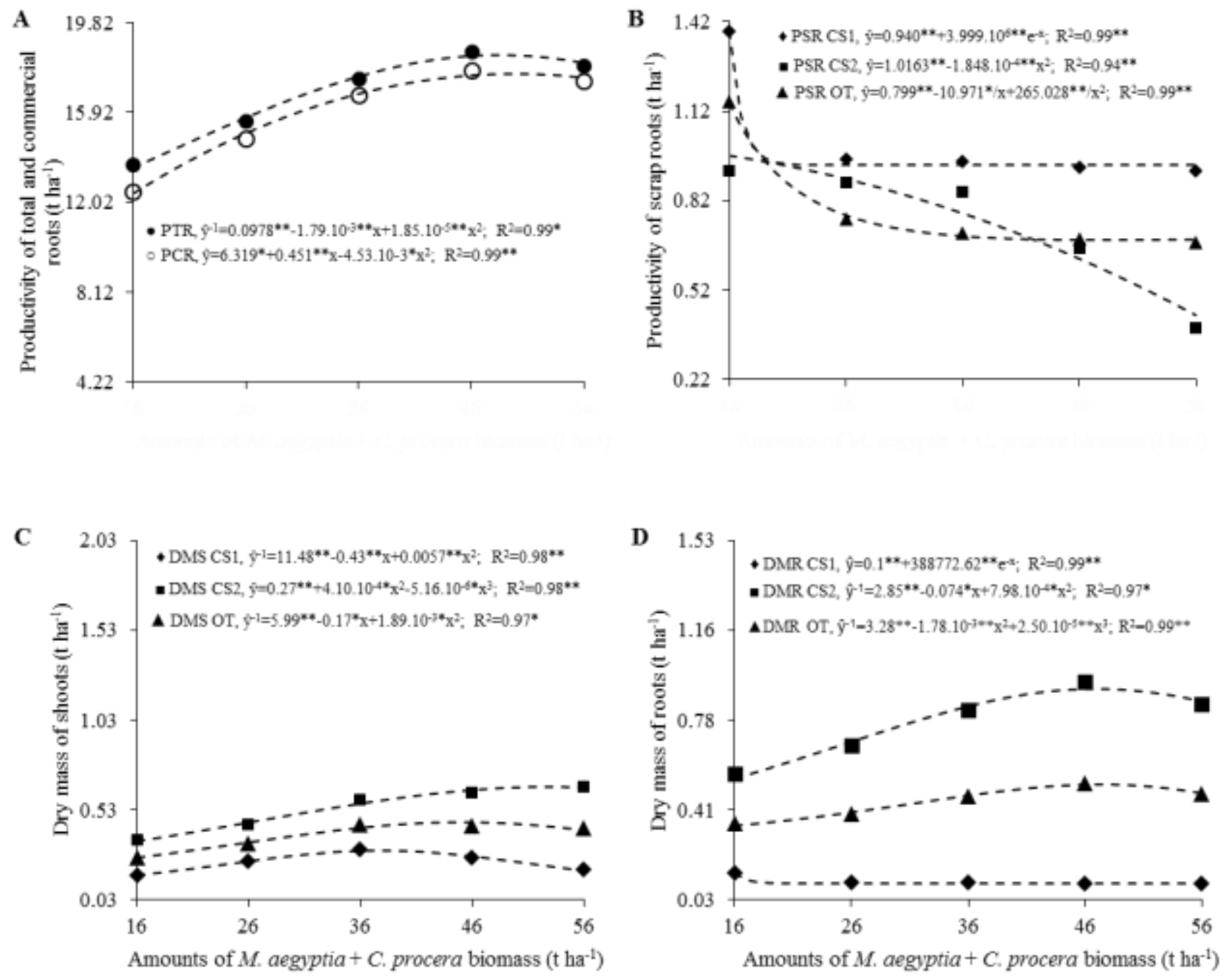

Source: Authors.

The total and commercial productivities of beetroot (Figures 1A; 4C and 4D) responded in a similar way to the dry masses of the shoots and roots, registering an increase with the increase of the amounts of biomass used in the manuring, in this way both vegetative and productive growth responded positively, increasing their biomass. The upward responses and the optimizations (in the obtaining MPE values) of the agronomic characteristics evaluated in the beetroot in polynomial or exponential models can be attributed to the Maximum Law, where the excess of a nutrient in the soil provided by equitable amounts of the $M$. aegyptia and $C$. procera mixture can cause a toxic effect and/or decrease the effectiveness of other factors, thus resulting in the reduction of the characteristic under analysis after the maximum point (Almeida et al., 2015). Another factor that may be related to this behavior of the tuberous vegetable is the proper synchrony between the decomposition and mineralization of green manures added to soil and time of the greatest nutritional demand of the culture (Souza et al., 2017). 
Morais et al. (2019) studying beetroot intercropping with cowpea fertilized with spontaneous Caatinga species obtained total and commercial productivities of beet roots of 15.74 and $12.96 \mathrm{t} \mathrm{ha}^{-1}$, respectively, when using amounts of $C$. procera biomass proceeding from $65 \mathrm{t} \mathrm{ha}^{-1}$. These productivity values were lower than those obtained by beetroot in monocropping, which were 18.40 and $17.58 \mathrm{tha}^{-1}$ manured with the amounts of 48.55 and $49.87 \mathrm{tha}^{-1}$ of the green manures biomass, M. aegyptia and C. procera. These differences in productivity are due to the type of cultivation system used, which in the present study was monocropping. In terms of the amounts of green manures that obtained these productivities, they were also lower in monocropping than in intercropping.

The dry mass (DM) of beet shoots increased with the increase of the green manures biomass amount incorporated in the soil, in a polynomial model, up to a maximum value of $0.30 \mathrm{t}$ ha- 1 in the first cropping season in the green manures amount of $37.77 \mathrm{t}$ ha-1 (Figure 1C). The DM of the shoots and roots in the second cropping season also increased with the increase in the green manure biomass amount, reaching the maximum values of 0.65 and $0.88 \mathrm{t}$ ha-1 with the biomass amounts of 52.93 and $46.92 \mathrm{t}$ ha-1 (Figures 1C and 1D). The maximum values of shoots and roots optimized DM of 0.47 and $0.51 \mathrm{t}$ ha-1 as a function of green manures amount, in the two seasons, were obtained with the green manures biomass amounts of 45.11 and $47.36 \mathrm{t}$ ha-1, respectively (Figures $1 \mathrm{C}$ and 1D).

The dry masses of the shoots and roots (Figures 1C and 1D; 4A and 4B) responded positively to the increase in the amounts of green manure biomass, until they reached the maximum efficiency and then decreased from that point. This type of behavior can be attributed to the law of decreasing increments, where the increase in excess nutrients in the soil does not lead to productive gains (Almeida et al., 2015). Others factors that may be possibly related are the adequate balance between the decomposition and the mineralization of green fertilizers added to the soil and the immobilization, beyond time of greatest nutritional demand of the crop (Souza et al., 2017). The highest values of these dry masses were obtained in the second growing season, due to the greater growth and development of the crop and also due to the more favorable climatic conditions in terms of temperature and relative humidity of the air of the second crop.

Studying the interactions of the productivities of extra and extra A roots, in the cropping seasons, it was observed increase in these productivities with the increased of green manures biomass amount incorporated in the soil, in polynomial or exponential model. The maximum values of 0.78 and $2.21 \mathrm{tha}^{-1}$ were obtained in the green manures biomass amount of $56.00 \mathrm{t}$ $\mathrm{ha}^{-1}$, in the first cropping season (Figures 2A and 2B). The productivities of roots extra A and extra AA also increased with the amounts of green manures biomass, reaching the maximum values of 2.97 and $4.86 \mathrm{t} \mathrm{ha}^{-1}$ in the biomass amounts of 35.22 and $56.00 \mathrm{t} \mathrm{ha}^{-1}$ in the second cropping season (Figures 2B and 2C). 
Figure 2. Productivity of extra roots - PE (A), productivity of extra A roots - PEA (B), productivity of extra AA roots - PEAA (C), and productivity of great roots - PGR (D) of beetroot as a function of equitable amounts of M. aegyptia and C. procera biomass in two cropping seasons (CS1 and CS2). ** $=\mathrm{P}<0.01 ; *=\mathrm{P}<0.05$; OT $=$ Optimized.
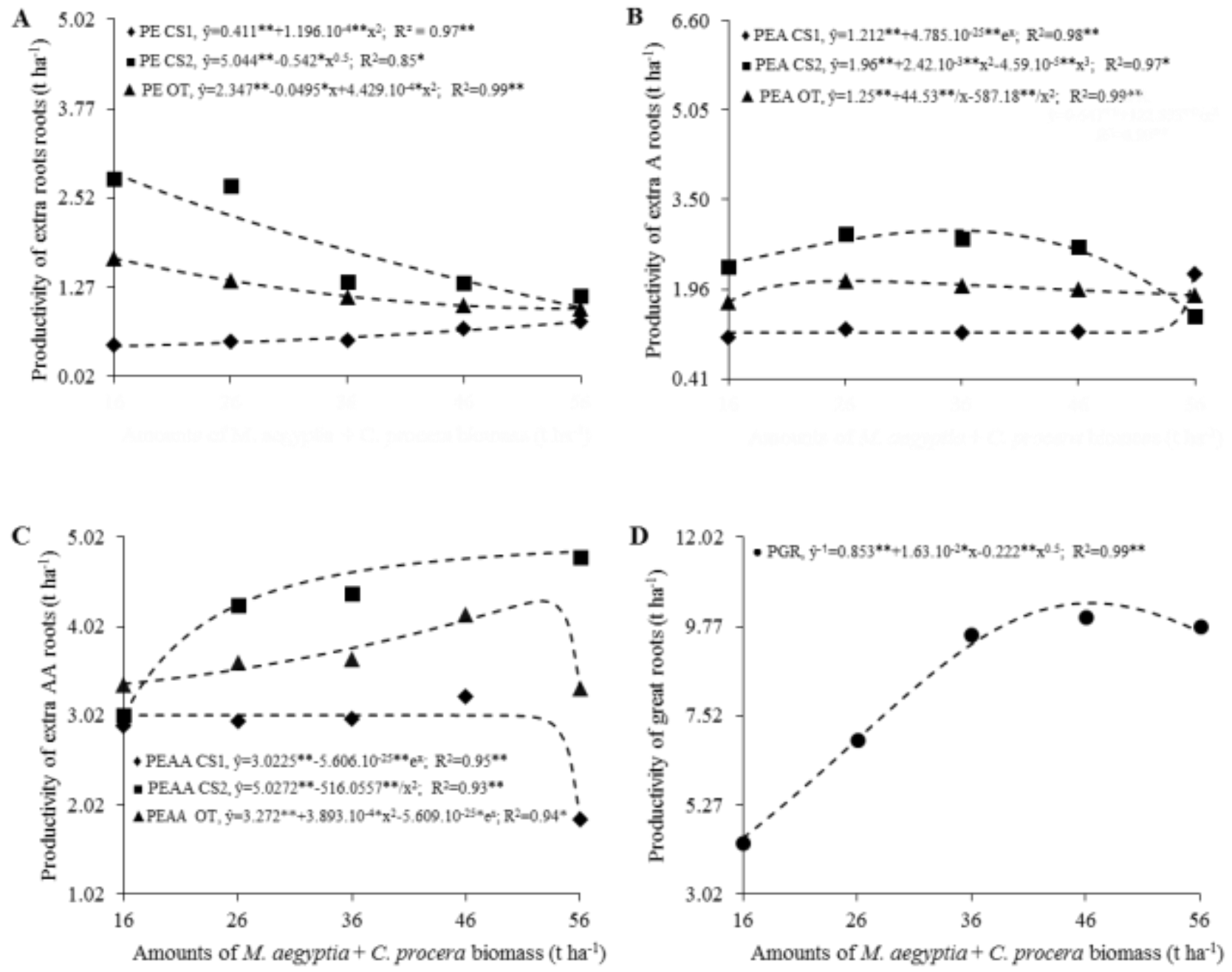

Source: Authors

On the other hand, a decrease was registered in the productivity of extra and extra AA roots with an increase in the amounts of biomass of green manures, reaching a maximum value of $2.87 \mathrm{t} \mathrm{ha}^{-1}$ in the productivity of extra roots with $16 \mathrm{t} \mathrm{ha} \mathrm{t}^{-1}$ of green manures in the second season, and $3.02 \mathrm{t} \mathrm{ha}^{-1}$ in the productivity of roots extra AA in the first cropping season, also with $16.00 \mathrm{t} \mathrm{ha}^{-1}$ of the biomass (Figures $2 \mathrm{~A}$ and $2 \mathrm{C}$ ). The optimized productivities of extra A and extra AA roots in the two seasons grew with the amounts of green manures biomass, reaching maximum values of 2.59 and $4.31 \mathrm{t} \mathrm{ha}^{-1}$ with biomass amounts of 26.37 and $52.64 \mathrm{t} \mathrm{ha}^{-1}$, respectively, while the optimized productivity of extra roots decreased with the quantities of green manures, reaching the maximum value of $1.67 \mathrm{t} \mathrm{ha}^{-1}$ with $16.00 \mathrm{t} \mathrm{ha}^{-1}$ of biomass (Figures $2 \mathrm{~B}, 2 \mathrm{C}$ and $2 \mathrm{~A}$ ).

The productivity of great roots increased with the increase of the amounts of biomass of M. aegyptia and C. procera

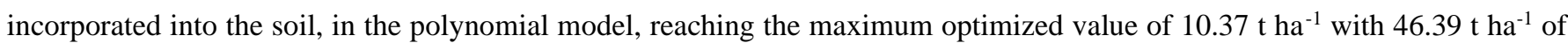
biomass (Figure 2D).

Silva et al. (2019), studying the performance of beetroot fertilized with M. aegyptia, obtained optimized productivities of 4.44; 6.12 and 13.85 for roots extra, extra A, and extra AA plus great, respectively, with the amounts of M. aegyptia biomass of $27.09 ; 33.53$ and $51.02 \mathrm{t} \mathrm{ha}^{-1}$. These results were different from those obtained in this research, where the productivities were 1.61; 2.59 and $14.68 \mathrm{t} \mathrm{ha}^{-1}$ (Figures 2A, 2B and 2C), for that same root classification with the amounts of 
the biomass mixture of C. procera and M. aegyptia of 16; 26.37 and $49.51 \mathrm{t} \mathrm{ha}^{-1}$. These differences between productivities are possibly due to the complementarity of the green manures, which provided better nutritional conditions for tuberoses and consequently a higher crop productivity.

The mean values of maximum physical efficiency (MPE) and of the treatments that received the M. aegyptia and $C$. procera manure $\left(T_{m}\right)$ differed statistically from the values of the control $\left(T_{c}\right)$ (Table 4$)$. In the production of dry masses of shoots and roots, these MPE values were 2.82 and 2.55 higher than the value of $\mathrm{T}_{\mathfrak{c}}$, respectively.

In the productivity of total and commercial roots and in the classified productivity of great, extra A, extra AA and scrap roots, the MPE values were respectively $2.56 ; 2.29 ; 1.46 ; 1.44$ and 2.77 higher than the value of the $\mathrm{T}_{\mathfrak{c}}$. In the productivity of beetroot extra roots, the MPE value was 1.12 times lower than that of the control treatment.

\subsection{Beetroot culture economic indicators}

Significant interactions were also recorded between the factors, amounts of the biomass mixture of M. aegyptia and $C$. procera and cropping seasons for all economic indicators evaluated on beetroot (Figure 3, Table 4).

Figure 3. Gross income - GI (A), net income - NI (B), rate of return - RR (C), and profit margin - PM (D) of the beetroot crop as a function of amounts of M. aegyptia and C. procera biomass in two cropping seasons (CS1 and CS2). ** $=\mathrm{P}<0.01 ; *=\mathrm{P}$ $<0.05$; OT $=$ Optimized.
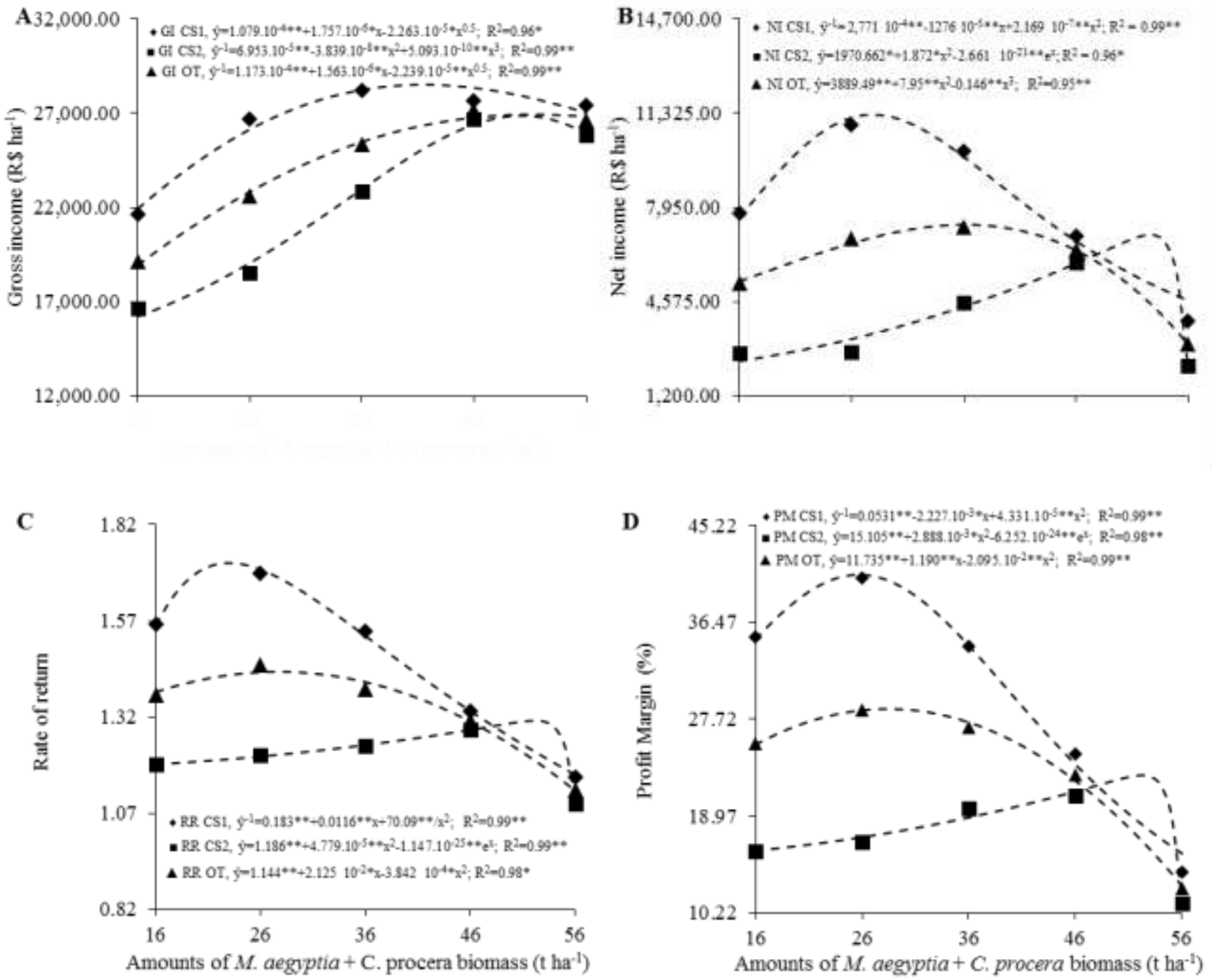

Source: Authors 
Partitioning the interactions between the factors, amounts of $M$. aegyptia and $C$. procera biomass and cropping seasons, an increase was observed in all economic indicators of beetroot, in the polynomial or exponential model, up to the maximum values of gross and net incomes, rate of return and profit margin of 28,545.39 and 11,202.16 R\$ ha-1 1.71 and $40.86 \%$, respectively, with biomass amounts of $41.44 ; 27.85 ; 24.68$ and $25.72 \mathrm{t} \mathrm{ha}^{-1}$ in the first cropping season, and maximum values of $26,870.83$ and $6,964.61 \mathrm{R} \$ \mathrm{ha}^{-1} ; 1.31$ and $22.68 \%$, with biomass amounts of $50.25 ; 52.65 ; 52.14$ and $52.22 \mathrm{t} \mathrm{ha}^{-1}$ in the second cropping season; then these values decreased until the greatest biomass amount was incorporated into the soil (Figures 3A, 3B, 3C and 3D).

Estimating the values of the maximum economic efficiency of the indicators over the cropping seasons, a behavior similar to those found within each growing season was also observed, with the values increasing up to a maximum of 26,942.76 and 7,380.83 R $\$ \mathrm{ha}^{-1} ; 1.44$ and $28.63 \%$ for M. aegyptia and C. procera biomass amounts of 51.28; 36.14; 27.60; $28.40 \mathrm{tha}^{-1}$, then decreasing until the incorporation of the last amount of these green manures (Figure 3).

The types of polynomial or exponential models tested in the characteristics of the beetroot fulfilled the selection criteria used to express the behavior of each evaluated characteristic. These were the biological logic (LB) of the variable, that is, when it turns out that after a certain dose of fertilizer there is no increase in productivity, the significance of the mean square of the regression residue (QMRR), a high value of the determination coefficient $\left(\mathrm{R}^{2}\right)$, the significance of the parameters of the regression equation, and the maximization of productivity and profit.

The mean values of maximum economic efficiency (MEE) and of treatments that received the M. aegyptia and $C$. procera manure $\left(\mathrm{T}_{\mathrm{m}}\right)$ differed statistically from the values of the control $\left(\mathrm{T}_{\mathrm{c}}\right)$ (Table 5$)$. For gross income, net income, rate of return and profit margin of beetroot, these MEE values were $12.15 ; 41.65 ; 1.42$ and 30.78 higher than the $\mathrm{T}_{\mathrm{c}}$ value, respectively.

\subsection{Agronomic characteristics of radish culture}

The results of the analyses of variance for the radish agronomic characteristics and economic indicators are presented in Table 5. Significant interactions were recorded between the amounts of the biomass mixture of M. aegyptia and C. procera and the cropping seasons for the most agronomic characteristics evaluated in the radish, except for the productivity of scrap roots (Table 5). 
Table 5. Mean values for the control (Tc), the treatment of maximum physical or economic efficiency (MPE or MEE) and of the manured treatments $\left(\mathrm{T}_{\mathrm{m}}\right)$ in the dry masses of shoots and roots, total and commercial productivities of roots, productivity of scrap roots, gross income, net income, rate of return and profit margin in the radish culture manured with $M$. aegyptia and $C$. procera biomass in two cropping systems.

\begin{tabular}{|c|c|c|c|c|c|c|}
\hline \multirow[t]{3}{*}{ Comparison treatments } & \multicolumn{3}{|c|}{$\begin{array}{c}\text { Dry mass of shoots } \\
\left(t \text { ha }^{-1}\right)\end{array}$} & \multicolumn{3}{|c|}{$\begin{array}{c}\text { Dry mass of roots } \\
\left(t \text { ha }^{-1}\right)\end{array}$} \\
\hline & \multicolumn{3}{|c|}{ Cropping seasons } & \multicolumn{3}{|c|}{ Cropping seasons } \\
\hline & 2016 & 2018 & 2016-2018 & 2016 & 2018 & 2016-2018 \\
\hline Control (without manuring, $\mathrm{T}_{\mathrm{c}}$ ) & $1.49 \mathrm{bA}$ & $0.75 \mathrm{bB}$ & $1.12 \mathrm{~b}$ & $0.22 \mathrm{bA}$ & $0.06 \mathrm{bB}$ & $0.14 \mathrm{~b}$ \\
\hline MPE treatment & $4.51 \mathrm{aA}$ & $1.78 \mathrm{aB}$ & $3.15 \mathrm{a}$ & $0.39 \mathrm{aA}$ & $0.13 \mathrm{aB}$ & $0.26 \mathrm{a}$ \\
\hline Manured treatments $\left(\mathrm{T}_{\mathrm{m}}\right)$ & & & $2.37^{+}$ & & & $0.25^{+}$ \\
\hline \multirow[t]{2}{*}{$\mathrm{CV}(\%)$} & & & 17.88 & & & 15.25 \\
\hline & \multicolumn{3}{|c|}{$\begin{array}{l}\text { Productivity of total roots } \\
\left(t \text { ha }^{-1}\right)\end{array}$} & \multicolumn{3}{|c|}{$\begin{array}{c}\text { Productivity of commercial roots } \\
\left(t \text { ha }^{-1}\right)\end{array}$} \\
\hline Control (without manuring, $\mathrm{T}_{\mathrm{c}}$ ) & $3.08 \mathrm{bB}$ & $2.13 \mathrm{bB}$ & $2.61 \mathrm{~b}$ & $2.64 \mathrm{bA}$ & $1.80 \mathrm{bB}$ & $2.22 \mathrm{~b}$ \\
\hline MPE treatment & $7.47 \mathrm{aA}$ & $6.13 \mathrm{aB}$ & $6.80 \mathrm{a}$ & $6.86 \mathrm{aA}$ & $5.74 \mathrm{aB}$ & $6.21 \mathrm{a}$ \\
\hline Manured treatments $\left(\mathrm{T}_{\mathrm{m}}\right)$ & & & $5.82^{+}$ & & & $5.24^{+}$ \\
\hline \multirow[t]{2}{*}{$\mathrm{CV}(\%)$} & \multirow{2}{*}{\multicolumn{3}{|c|}{$\begin{array}{c}15.15 \\
\begin{array}{c}\text { Productivity of scrap roots } \\
(\mathbf{t ~ h a - 1})\end{array}\end{array}$}} & & & 18.77 \\
\hline & & & & & & \\
\hline Control (without manuring, $\mathrm{T}_{\mathrm{c}}$ ) & & & $0.39 \mathrm{~b}$ & & & \\
\hline MPE treatment & & & $0.61 \mathrm{a}$ & & & \\
\hline Manured treatments $\left(\mathrm{T}_{\mathrm{m}}\right)$ & & & $0.57^{+}$ & & & \\
\hline Cropping season 2016 & & & $0.78 \mathrm{a}$ & & & \\
\hline Cropping season 2018 & & & $0.30 \mathrm{~b}$ & & & \\
\hline \multirow[t]{2}{*}{$\mathrm{CV}(\%)$} & & & 41.27 & & & \\
\hline & & $\begin{array}{l}\text { Gross income } \\
\quad\left(\mathbf{R} \$ \mathbf{h a}^{-1}\right)\end{array}$ & & & $\begin{array}{l}\text { Net income } \\
\left(\mathbf{R} \$ \mathrm{ha}^{-1}\right)\end{array}$ & \\
\hline Control (without manuring, $\mathrm{T}_{\mathrm{c}}$ ) & $12,207.36 \mathrm{bA}$ & $9,367.68 \mathrm{bB}$ & $10,787.52 \mathrm{~b}$ & $820.52 \mathrm{bA}$ & $259.43 \mathrm{bB}$ & $539.98 \mathrm{~b}$ \\
\hline MPE treatment & $27,186.15 \mathrm{aA}$ & $23,415.99 \mathrm{aB}$ & $25,071.48 \mathrm{a}$ & $11,490.84 \mathrm{aA}$ & $6,284.12 \mathrm{aB}$ & $8,857.20 \mathrm{a}$ \\
\hline Manured treatments $\left(\mathrm{T}_{\mathrm{m}}\right)$ & & & $22,578.72^{+}$ & & & $6,258.62^{+}$ \\
\hline \multirow[t]{2}{*}{$\mathrm{CV}(\%)$} & \multirow{2}{*}{\multicolumn{3}{|c|}{ Rate of return }} & & & 35.86 \\
\hline & & & & \multicolumn{3}{|c|}{ Profit margin (\%) } \\
\hline Control (without manuring, $\mathrm{T}_{\mathrm{c}}$ ) & $1.07 \mathrm{aB}$ & $1.03 \mathrm{bB}$ & $1.05 \mathrm{~b}$ & $6.71 \mathrm{aB}$ & $2.71 \mathrm{bB}$ & $4.71 \mathrm{~b}$ \\
\hline MPE treatment & $1.56 \mathrm{aA}$ & $1.22 \mathrm{aB}$ & $1.39 \mathrm{a}$ & $37.93 \mathrm{aA}$ & $25.56 \mathrm{aB}$ & $32.16 \mathrm{a}$ \\
\hline Manured treatments $\left(\mathrm{T}_{\mathrm{m}}\right)$ & & & $1.25^{+}$ & & & $25.58^{+}$ \\
\hline $\mathrm{CV}(\%)$ & & & 12.98 & & & 39.34 \\
\hline
\end{tabular}

* Means followed by the same small letter in the column and capital letter in the row do not differ by $\mathrm{F}$ test at the 5\% probability.

${ }^{+}$Mean of manured treatments is significantly different from the control treatment mean by the $\mathrm{F}$ test at the 5\% probability level.

Source: Authors.

Partitioning the interactions that occurred in the dry masses of the shoots and roots and in the total and commercial productivities of radish roots, it was observed that there was an increase in these characteristics with the increase in the $M$. aegyptia and $C$. procera biomass amounts incorporated into the soil, in an exponential or polynomial model, reaching the maximum values (see the equations) of $4.50 ; 0.39 ; 7.47$ and $6.86 \mathrm{t} \mathrm{ha}^{-1}$ in the first cropping season with $53.48 ; 53.13 ; 40.48$ and $35.70 \mathrm{t} \mathrm{ha}^{-1}$ of green manures, and 1.78; 0.13; 6.13 and $5.74 \mathrm{t} \mathrm{ha}^{-1}$ in the second cropping season with 49.94; 33.30; 46.94 and $46.63 \mathrm{t} \mathrm{ha}^{-1}$ of green manures (Figures 4A, 4B, 4C and 4D). The dry masses of shoots and roots and the optimized total and commercial productivities of radish roots over the seasons also increased with the amounts of the green manures, reaching the maximum values (see the equations) of 3.37; 0.26; 6.72 and $6.21 \mathrm{t} \mathrm{ha}^{-1}$ with $53.60 ; 41.55 ; 40.55$ and $39.43 \mathrm{t} \mathrm{ha}^{-1}$ of manures incorporated (Figure 4). 
Figure 4. Dry masses of shoots - DMS (A), dry mass of roots - DMR and productivity of scrap roots - PSR (B), productivity of total roots - PTR (C), and productivity of commercial roots (D) of radish as a function of amounts of $M$. aegyptia and $C$. procera biomass in two cropping seasons $(\mathrm{CS} 1$ and $\mathrm{CS} 2)$. ** $=\mathrm{P}<0.01 ; *=\mathrm{P}<0.05 ; \mathrm{OT}=$ Optimized.
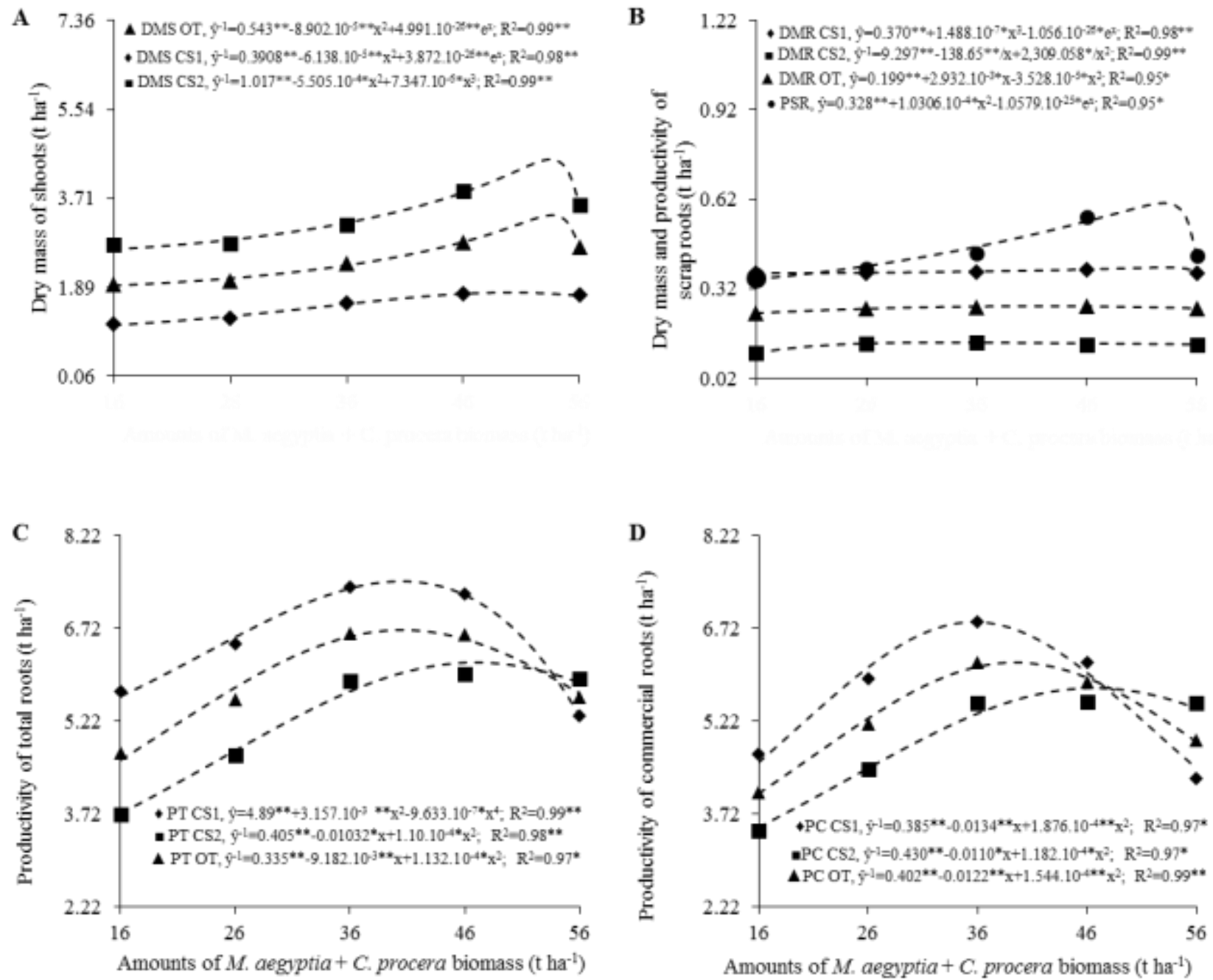

Source: Authors.

The productivity of scrap roots increased with the increase in the amounts of $M$. aegyptia and $C$. procera biomass incorporated into the soil, in the exponential model, reaching the maximum value of $0.60 \mathrm{t} \mathrm{ha}^{-1}$ for $52.99 \mathrm{t} \mathrm{ha}^{-1}$ of $_{\text {green }}$ manures biomass (Figure 4).

The mean values of maximum physical efficiency (MPE) and the treatments that received the M. aegyptia and $C$. procera manure $\left(\mathrm{T}_{\mathrm{m}}\right)$ differed statistically from the values of the control $\left(\mathrm{T}_{\mathrm{c}}\right)$ in the production of dry masses of shoots and roots, in the total and commercial productivities of roots and in the productivity of scrap roots. These MPE values were 2.81; $1.86 ; 2.60 ; 2.79$ and 1.56 higher than the value of $\mathrm{T}_{\mathrm{c}}$, respectively (Table 2).

\subsection{Radish culture economic indicators}

Regarding the economic indicators of the radish, there were significant interactions between the amounts of biomass mixtures of M. aegyptia and C. procera and the cropping seasons (Figure 5, Table 5). 
Figure 5. Gross income - GI (A), net income - NI (B), rate of return RR (C) and profit margin - PM (D) of radish as a function of amounts of $M$. aegyptia and $C$. procera biomass in two cropping seasons (CS1 and CS2). $* *=\mathrm{P}<0.01 ; *=\mathrm{P}<0.05 ; \mathrm{OT}=$ Optimized.
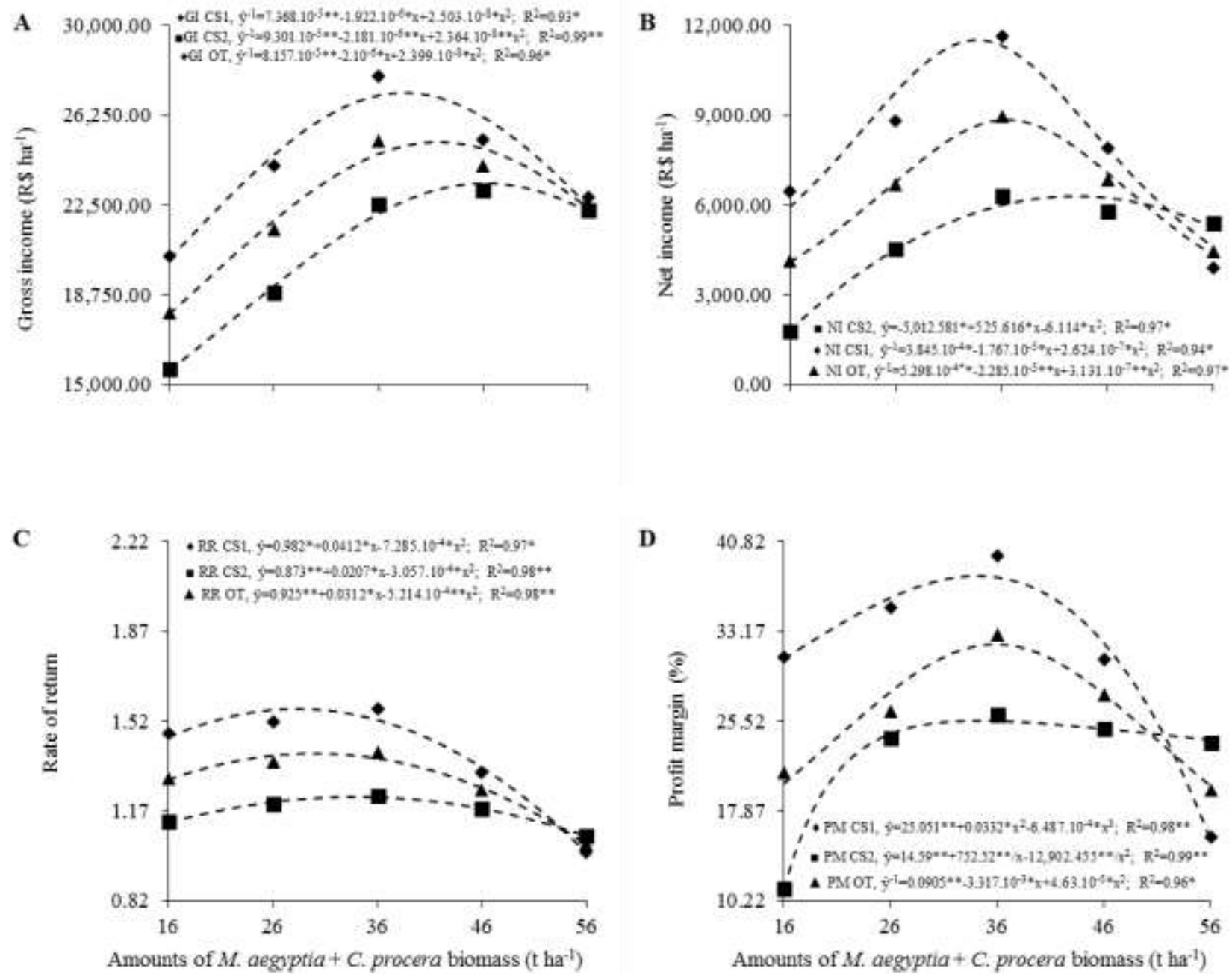

Amounts of $M$. aegrptia + C. procera biomass $\left(\mathrm{t} \mathrm{ha}^{-1}\right)$

Source: Authors.

Partitioning the interactions, there was an increase in these indicators as a function of the amounts of the green manures biomass mixture, up to the maximum values of $27,186.14 ; 11,490.84 \mathrm{R} \$ \mathrm{ha}^{-1} ; 1.56$ and $37.93 \%$ with biomass amounts of $38.39 ; 33.67 ; 28.31$ and $34.11 \mathrm{t} \mathrm{ha}^{-1}$ respectively, in the first cropping season. In the second cropping season, the maximum values reached were $23,415.99 ; 6,284.12 \mathrm{R} \$ \mathrm{ha}^{-1} ; 1.22$ and $25.56 \%$ with the biomass amounts of $46.11 ; 42.98 ; 33.90$ and 34.29 $\mathrm{t} \mathrm{ha}^{-1}$ of green manures, then decreasing until the last biomass amount incorporated (Figure 5).

Estimating the values of maximum economic efficiency of the indicators over the cropping seasons, a behavior similar to those found within each growing season was also observed, with an increase of the values up to a maximum of $25,071.47$ and $8,857.20 \mathrm{R} \mathrm{ha}^{-1} ; 1.39$ and $32.16 \%$ for biomass amounts of $M$. aegyptia and . procera of $41.68 ; 36.48 ; 29.95 ; 35.81 \mathrm{t} \mathrm{ha}$ 1 , then decreasing until the incorporation of the last quantity of these green manures (Figure 5).

The mean values of maximum economic efficiency (MEE) and of the treatments that received the M. aegyptia and C. procera manure $\left(\mathrm{T}_{\mathrm{m}}\right)$ differed statistically from the values of the control $\left(\mathrm{T}_{\mathrm{c}}\right)($ Table 5$)$. For gross income, net income, rate of 
return, and the radish profit margin, these MEE values were $2.32 ; 16.40 ; 1.32$ and 6.82 higher than the value of $\mathrm{T}_{\mathrm{c}}$, respectively.

The maximum physical efficiency (MPE) of the beetroot and radish treatments that received green manure were translated into economic terms in all the evaluated indicators, thus providing an optimized economic efficiency over the growing seasons (Tables 4 and 5). This behavior allows the beetroot grower to choose the optimum amount of green manure for incorporation and the economic indicator that best suits him in terms of productivity.

It is notable that the cultivation of beetroot and radish using a combination of two species of green manure provides a financial return that is compatible with the capital invested, thus becoming a viable alternative, especially for those small producers who do not have very high investment capital (Batista et al., 2016). In addition, it should be noted that spontaneous species for use in the manuring are readily available in the region.

The results obtained in these experiments are in agreement with those obtained by Silva et al. (2011) and Silva et al. (2019), working with the cultivation of beetroot in monocropping, as well as those obtained by Nunes et al. (2020) for radish monocropping.

The performance of the radish was similar to that of beetroot in terms of the regression models evaluated, where polynomial or exponential models were estimated to represent the agronomic and economic behavior of the performance of the characteristics evaluated in radish.

As in the culture of beetroot, the production of radish using two species of green manures provided good profitability, resulting in an economic return compatible with the capital invested, thus constituting a viable production alternative for tuberose vegetable producers.

The upward responses of the economic indicators evaluated in both tuberous crops in polynomial or exponential form and the economic optimizations as a function of the equitable amounts of the mixture of M. aegyptia and C. procera was because the tuberous crops responded very well to green manures. The environmental resources, provided by the quantities of the mixtures tested, were better used by beetroot and radish plants, whose use was translated into economic efficiency. Green manuring is known to improve fertility, increase organic matter content, decrease erosion rates, increase soil water retention and soil microbiota activity, increase nutrient availability, and reduce the amount of invasive plants (Pereira et al., 2016).

Nunes et al. (2020), trying to optimize the radish productivity with applications of $M$. aegyptia in the semi-arid region

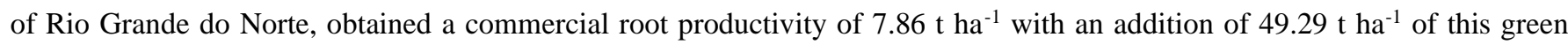
manure, and an optimized maximum economic efficiency of 11,955.46 R\$ ha-1, when adding the dose of $46.00 \mathrm{tha}^{-1}$ of $M$. aegyptia. In this research, a productive and economic efficiency of $6.21 \mathrm{t} \mathrm{ha}^{-1}$ and $8,857.20 \mathrm{R} \$ \mathrm{ha}^{-1}$ was obtained with additions of 39.43 and $36.48 \mathrm{t} \mathrm{ha}^{-1}$ of the mixture of $M$. aegyptia and C. procera. This difference is due to the nutritional complementarity sponsored by the combination of green manures, which provides a satisfactory agronomic and economic efficiency and a decrease in the amount of green manures needing to be incorporated. Thus, these agroeconomic optimizations allow the producer of these tuberous cultures to decide on the recommendation of the amounts of the green manure mixtures of $M$. aegyptia and $C$. procera that best suits him in agronomic and economical terms.

Comparing the total yields of beet roots $\left(18.40 \mathrm{t} \mathrm{ha}^{-1}\right)$ and radish $\left(7.47 \mathrm{t} \mathrm{ha}^{-1}\right)$ fertilized with M. aegyptia and $C$. procera obtained in this research with the average yields (40.94 and $\left.16.60 \mathrm{t} \mathrm{ha}^{-1}\right)$ of these tuberoses in the region, fertilized with chemical fertilizer, it was recorded that the yield of these crops obtained with green manures was about half of those obtained with chemical manure. 


\section{Conclusions}

The maximum agronomic efficiency (commercial productivity) of beetroot and radish was possible with the incorporation of the doses of 49.87 and $39.43 \mathrm{t} \mathrm{ha}^{-1}$ of Merremia aegyptia and Calotropis procera, respectively, and the maximum economic efficiency of production of these tuberous vegetables was reached with the addition to the soil of 36.14 and $36.48 \mathrm{t} \mathrm{ha}^{-1}$ of the biomass of these green manures, respectively. The rates of return obtained in the cultivation of beetroot and radish with the optimized amounts of the manures combination were 1.42 and 1.32 reais obtained for each real invested in the production of these tuberous. The $M$. aegyptia and $C$. procera biomass use from Caatinga biome proved to be a viable technology for growers who practice the cultivation of beetroot and radish monocropping in semi-arid environment. This cultivation system should be recommended to family growers who produce tuberous vegetables in a sustainable form in semiarid ambient. Finally, there is an immediate need for investigate on the adequate management of production factors such as: organic fertilization type, mode and adequate time of application, as well as the ideal establishment of irrigation blade during the conduction of the cultures in the field.

\section{Acknowledgments}

We would like to thank the National Council for Scientific and Technological Development (CNPq/Brazil), for the research financial support (process $n^{\circ} 305222 / 2019-8$ ) and for grant number 88887.217232/2018-00 for the doctorate student.

\section{References}

Aguiar, F. R., França, A. C., Cruz, R. S., Sardinha, L. T., Machado, C. M. M., Ferreira, B. O., \& Araújo, F. H. V. (2021). Produção e qualidade de beterrabas submetidas a diferentes manejos de adubação e efeito residual na produção de milho cultivado em sucessão. Journal of Environmental Analysis and Progress, 6 (1), 60-70. 10.24221/jeap.6.1.2021.3043.060-070

Almeida, A. E. S., Bezerra Neto, F., Costa, L. R., Silva, M. L., Lima, J. S. S., \& Barros Júnior, A. P. (2015). Eficiência agronômica do consórcio alface-rúcula fertilizado com flor-de-seda. Revista Caatinga, 28 (3), 79-85. 10.1590/1983-21252015v28n309rc

Batista, M. A. V., Bezerra Neto, F., Silva, M. L., Ambrósio, M. M. Q., \& Cunha, J. L. X. L. (2016). Atributos de solo-planta e de produção de beterraba influenciados pela adubação com espécies da Caatinga. Horticultura Brasileira, 34 (1), 31-38. 10.1590/S0102-053620160000100005

Beck, H., Zimmermann, N. E., Mcvicar, T., Vergopolan, N., Berg, A., \& Wood, E. F. (2018). Data descriptor: Present and future Köppen-Geiger climate classification maps at 1-km resolution. Scientific Data, 5, 180214. 10.1038/sdata.2018.214

Bezerra Neto, F., Silva, M. L., Lima, J. S. S., Barros Júnior, A. P., Silva, I. N., \& Chaves, A. P. (2019). Productive viability and profitability of carrot-cowpea intercropping using different amounts of Calotropis procera. Revista Caatinga, 32(1), 62-71. 10.1590/1983-21252019v32n107rc

EMATER-DF. (2021). SisCustos de produção. https://emater.df.gov.br/custos-de-producao/

Favacho, F. S., Lima, J. S. S., Bezerra Neto, F., Silva, J. N., \& Barros Júnior, A. P. (2017). Productive and economic efficiency of carrot intercropped with cowpea vegetable resulting from green manure and different spatial arrangements. Revista Ciência Agronômica, 48(2), 337-346. 10.5935/18066690.20170039

Ferreira, D. F. (2019). Sisvar: A computer analysis system to fixed effects split plot type design. Revista Brasileira de Biometria, 37(4), 529-535, 2019. $10.28951 /$ rbb.v37i4.450

IBGE - Instituto Brasileiro de Geografia e Estatística. (2021). Censo Agropecuário 2017. Rio de Janeiro: Ministério da Economia. Disponível em: https://sidra.ibge.gov.br.

INMET - Instituto Nacional de Meteorologia. (2019). Dados meteorológicos. Brasilia: Ministério da Agricultura, Pecuária e Abastecimento, Disponível em: https://portal.inmet.gov.br.

Martins, J. K. D., Luz, S. R. O. T., Ferreira, A. G., \& Silva, C. A. (2017). Aplicação de duas fontes de adubação nitrogenada submetida a doses crescentes na cultura do rabanete (Raphanus sativus L.) na Amazônia ocidental. Agrarian Academy, 4(8), 68. 10.18677/Agrarian_Academy_2017b7

Morais, E. C., Lima, J. S. S., Bezerra Neto, F., Silva, J. N., Nunes, R. L. C., \& Linhares, P. C. A. (2018). Habilidade competitiva e biológica do consórcio beterraba com caupi-hortaliça proveniente de adubação verde e de arranjos espaciais. Revista Ceres, 65(5), 433-442. 10.1590/0034-737X201865050008 
Research, Society and Development, v. 10, n. 16, e66101623205, 2021

(CC BY 4.0) | ISSN 2525-3409 | DOI: http://dx.doi.org/10.33448/rsd-v10i16.23205

Morais, E. C., Lima, J. S. S., Bezerra Neto, F., Linhares, P. C. A., Costa, A. P., Crispim, J. F., Andrade, L. I. F., \& Rodrigues, G. S. O. (2019). Effects of different roostertree (Calotropis procera) amounts and spatial arrangements on the performance of the beet-cowpea intercropping system. Australian Journal of Crop Science, 13(4), 486-493. 10.21475/ajcs.19.13.04.p843

Nunes, R. L. C., Bezerra Neto, F., Lima, J. S. S., Chaves, A. P., Silva, J. N., \& Santos, E. C. (2020). Effect of green manuring with Merremia aegyptia on agro-economic efficiency of radish production. Revista Caatinga, 33(4), 964-973. 10.1590/1983-21252020v33n411rc

Pereira, M. F. S., Bezerra Neto, F., Pontes, F. S. T., Linhares, P. C. F., Silva, M. L., \& Silva, Í. N. (2016). Productive performance of cowpea-radish intercropping under different amounts of rooster tree biomass incorporated into the soil. Revista Brasileira de Engenharia Agrícola e Ambiental, 20(11), 965971. 10.1590/1807-1929/agriambi.v20n11p965-971

Santos, C. A., Oliveira, A. B., Rocha, I. A., \& Freitas, P. G. N. (2020). Beterraba: A raiz forte da terra. Uberlândia, MG: Revista Campo \& Negócios. Disponível em: https://revistacamposnegócio.com.br/beterraba-a-raiz-forte-da-terra

Santos, H. G., Jacomine, P. K. T., Anjos, L. H. C., Oliveira, V. A., Lumbreras, J. F., Coelho, M. R., Almeida, J. A., Cunha, T. J. F., \& Oliveira, J. B. (2018). Sistema brasileiro de classificação de solos. Brasília: Embrapa, 356 p.

Silva, I. N., Bezerra Neto, F., Barros Júnior, A. P., Lima, J. S. S., Chaves, A. P., Nunes, R. L. C., Lins, H. A., \& Albuquerque, J. R. T. (2019). Agro-biological and economic efficiency in a beetroot (Beta vulgaris L.) production system fertilized with hairy woodrose (Merremia aegyptia (L.) Urb.) as green manure. Australian Journal of Crop Science, 13(3), 395-402. 0.21475/ajcs.19.13.03.p1297

Silva, J. N., Bezerra Neto, F., Lima, J. S. S., Santos, E. C., Nunes, R. L. C., \& Chaves, A. P. (2020). Production and benefits in carrot and vegetable cowpea associations under green manuring and spatial arrangements. Revista Ciência Agronômica, 51(4), 1-11, 2020. 10.5935/1806-6690.20200064

Silva, M. L., Bezerra Neto, F., Linhares, P. C. F., Sá, J. R., Lima, J. S. S., \& Barros Júnior, A. P. (2011). Produção de beterraba fertilizada com jitirana em diferentes doses e tempos de incorporação ao solo. Revista Brasileira de Engenharia Agrícola e Ambiental, 15 (8), 801-809. 10.1590/S1415-43662011 000800006

Souza, E. G. F., Lima, E. F., Barros Júnior, A. P., Silveira, L. M., Bezerra Neto, F., \& Cruz, E. A. (2017). Production of lettuce under green manuring with Calotropis procera in two cultivation seasons. Revista Caatinga, 30 (2), 391-400. 10.1590/1983-21252017v30n214rc

Souza, Pablo Porto. Influence of Organic and Mineral Fertilizer on early development of culture-Italian Zucchini (Cucurbita pepo). Multidisciplinary Core scientific journal of knowledge. 02, 133-145.

Systat Software Inc. 2021. Table curve 3D Academic Edition. Systat Software Inc. 